\title{
Generalized polyspike train
}

An EEG biomarker of drug-resistant idiopathic generalized epilepsy

Neurology ${ }^{\circledR}$ 2018;91:1117. doi:10.1212/WNL.0000000000006797

In the article "Generalized polyspike train: An EEG biomarker of drug-resistant idiopathic generalized epilepsy" by Sun et al., ${ }^{1}$ one author's name should read as Kee Meng Tan. The authors regret the errors.

\section{Reference}

1. Sun Y, Seneviratne U, Perucca P, et al. Generalized polyspike train: an EEG biomarker of drug-resistant idiopathic generalized epilepsy. Neurology 2018;91:e1822-e1830.

\section{Novel biomarker signatures for idiopathic REM sleep behavior disorder}

A proteomic and system biology approach

Neurology ${ }^{\circledR}$ 2018;91:1117. doi:10.1212/WNL.0000000000006791

In the article "Novel biomarker signatures for idiopathic REM sleep behavior disorder: A proteomic and system biology approach" by Mondello et al., ${ }^{1}$ the institution for Dr. Giuseppe Plazzi, Dr. Elena Antelmi, and Dr. Monica Moresco should read as the "University of Bologna and IRCCS Istituto delle Scienze Neurologiche di Bologna, Bologna, Italy.” The authors regret the error.

\section{Reference}

1. Mondello S, Kobeissy F, Mechref Y, et al. Novel biomarker signatures for idiopathic REM sleep behavior disorder: a proteomic and system biology approach. Neurology 2018;91:e1710-e1715.

\section{Practice guideline update summary: Efficacy and tolerability of the new antiepileptic drugs II: Treatment-resistant epilepsy}

Report of the Guideline Development, Dissemination, and Implementation Subcommittee of the American Academy of Neurology and the American Epilepsy Society

Neurology ${ }^{\circledR}$ 2018;91:1117. doi:10.1212/WNL.0000000000006636

In the article "Practice guideline update summary: Efficacy and tolerability of the new antiepileptic drugs II: Treatment-resistant epilepsy" by Kanner et al., ${ }^{1}$ there is an error in the abstract, which should have read "2004 criteria were used to systematically review literature" rather than "...systemically review..." as originally published. The authors regret the error.

\section{Reference}

1. Kanner AM, Ashman E, Glass D, et al. Practice guideline update summary: efficacy and tolerability of the new antiepileptic drugs II: treatment-resistant epilepsy. Neurology 2018;91:82-90. 


\section{Neurology}

Practice guideline update summary: Efficacy and tolerability of the new antiepileptic drugs II: Treatment-resistant epilepsy: Report of the Guideline Development, Dissemination, and Implementation Subcommittee of the American Academy of Neurology and the American Epilepsy Society Neurology 2018;91;1117

DOI 10.1212/WNL.0000000000006636

This information is current as of December 10, 2018

Updated Information \& Services

References

Permissions \& Licensing

Reprints including high resolution figures, can be found at: http://n.neurology.org/content/91/24/1117.3.full

This article cites 1 articles, 1 of which you can access for free at: http://n.neurology.org/content/91/24/1117.3.full\#ref-list-1

Information about reproducing this article in parts (figures,tables) or in its entirety can be found online at:

http://www.neurology.org/about/about_the_journal\#permissions

Information about ordering reprints can be found online: http://n.neurology.org/subscribers/advertise

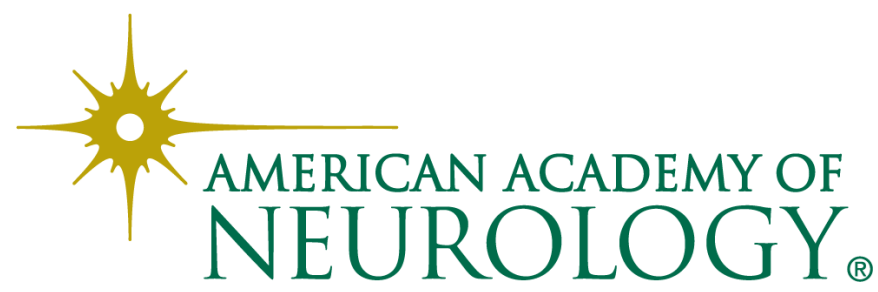

